Document downloaded from:

http://hdl.handle.net/10251/104778

This paper must be cited as:

Hernández Crespo, C.; Gargallo Bellés, S.; Benedito Durá, V.; Nacher Rodriguez, B.; Rodrigo-Alacreu, MA.; Martín Monerris, M. (2017). Performance of surface and subsurface flow constructed wetlands treating eutrophic waters. The Science of The Total Environment. 595:584-593. doi:10.1016/j.scitotenv.2017.03.278

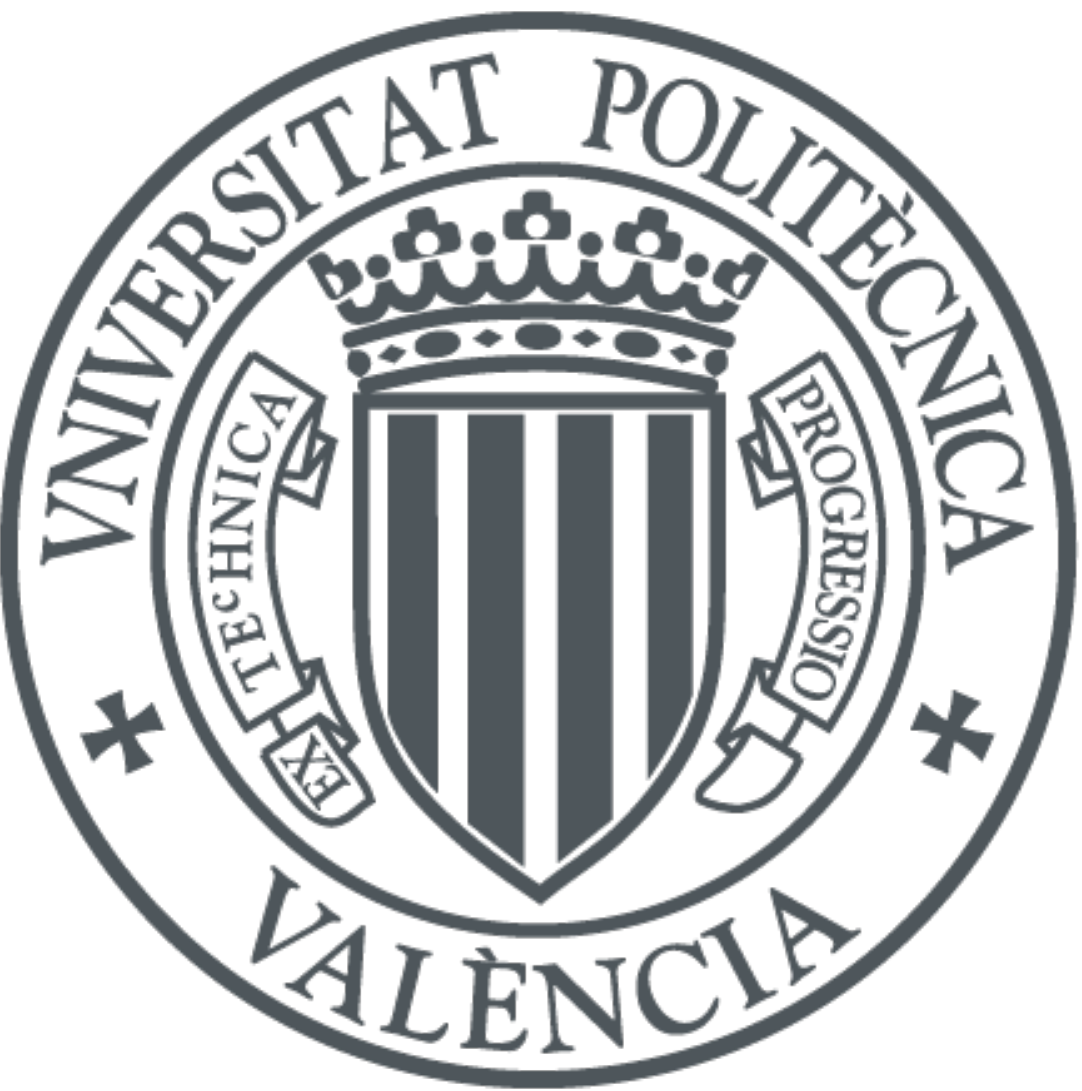

The final publication is available at

https://doi.org/10.1016/j.scitotenv.2017.03.278

Copyright Elsevier

Additional Information 


\title{
PERFORMANCE OF SURFACE AND SUBSURFACE FLOW CONSTRUCTED WETLANDS TREATING EUTROPHIC WATERS
}

\author{
C. Hernández-Crespo ${ }^{1}$, S. Gargallo ${ }^{1}$, V. Benedito-Durá2, Beatriz Nácher-Rodríguez ${ }^{1}$, M.A. Rodrigo- \\ Alacreu $^{3}, \underline{\text { M. Martín }}{ }^{1}$
}

${ }^{1}$ Institute of Water Engineering and Environment. Technical University of Valencia, Valencia, SPAIN (carhercr@upv.es; sagarbel@upv.es; beanacro@cam.upv.es; mmartin@hma.upv.es)

${ }^{2}$ Department of Hydraulic Engineering and Environment, Technical University of Valencia, Valencia, SPAIN (vibedu@hma.upv.es)

${ }^{3}$ Integrative Ecology Group, Cavanilles Institute for Biodiversity and Evolutionary Biology, University of Valencia, Catedrático José Beltrán 2. E-46980-Paterna, Valencia, Spain

Keywords: biodiversity, constructed wetland; eutrophication; phytoplankton; total phosphorus.

\section{ABSTRACT}

Three medium size constructed wetlands (CWs) with a total surface of 90 ha are working since 2009 in the Albufera de Valencia Natural Park (Spain). Two of them are fed with eutrophic waters from L'Albufera Lake. Their objectives are both reduce the phytoplankton biomass and increase the biodiversity; consequently, improved water quality is returned to the lake. A "science based governance" of these CWs is ongoing inside the LIFE+12 Albufera Project to demonstrate the environmental benefits of these features. In this paper, results and relationships among hydraulic operation, physicochemical variables and plankton in two different CWs typologies, five free water surface CW (FWSCW) and one horizontal subsurface flow CW (HSSFCW), were analysed showing that $\mathrm{CWs}$ were capable of improving the water quality and biodiversity but showing clear differences depending on the CW type. The CWs worked under different hydraulic load rates (HLR) from less than 0.12 to $54.75 \mathrm{~m} \mathrm{yr}^{-1}$. Inflow water quality was typical from eutrophic waters with mean values of chlorophyll $a(\mathrm{Chl} a)$ about 22-90 $\mu \mathrm{g} \mathrm{Chl} a l^{-1}$ and mean total phosphorus (TP) between 0.122-0.337 $\mathrm{mg}^{-1}$. The main conclusion is that HSSFCW was much more efficient than FWSCW in the removal of organic matter, suspended solids and nutrients. The biological role of several shallow lagoons located at the end of the CWs has also been evaluated, showing that they contribute to increase the zooplankton biomass, a key factor to control the phytoplankton blooms.

\section{Introduction}

Eutrophication of water masses is a widespread problem at a global level. Once established, come back to the previous ecological status is a nearly impossible task and only a fraction of this "ideal" status can be achieved. In natural wetlands, the loose of their ecosystem services linked to biodiversity has dramatically increased because of the water deterioration. The efforts in recover these lost services are increasing and new uses of well known technologies are being put in practice. One example is the use of constructed wetlands (CW) as green infrastructures close to natural wetlands with the objective of removing total suspended solids (TSS), phytoplankton and nutrients from water, increasing transparency, making easier the vegetation recovery and enhancing biodiversity. Constructed wetlands, mainly horizontal (HSSFCWs) or vertical subsurface flow constructed wetlands (VSFCWs), are widely used to treat sewage from small communities and many other types of wastewater, with excellent results in organic matter $\left(80.7 \% \mathrm{BOD}_{5}\right.$ removal) and total 
suspended solids (68.1\%) but not for total nitrogen (39.4\%) and total phosphorus (40.9\%), (Vymazal, 2008). The use of CWs to help recovering eutrophic water bodies in natural sites (protected areas as Natura 2000 sites in Europe) is still low, but growing. Several studies using full scale free water surface flow constructed wetlands have demonstrated proper mass removal efficiencies in physicochemical components. For instance, Dunne et al. $(2012,2013,2015)$ have reported $30-67 \%$ for total phosphorus (TP) and 30-52\% for total nitrogen (TN) and TP in full scale FWSCWs built to treat the water from Lake Apopka (Florida, USA). In Spain, the experience reported in Lake Albufera (Valencia, Spain) provides also high performance for TSS 57\%, TP 57\%, TN 52\% and the phytoplankton pigment Chlorophyll a 35\% (Martin et al. 2013). On the other hand, the study carried out by Li et al. (2008) with three types of pilot scale CW (free water surface, horizontal and vertical subsurface flow) in China shows nutrient removal $20-52 \%$ for TN and $35-66 \%$ for TP treating waters from Taihu Lake. These results are comparable to those for urban wastewater aforementioned and reviewed by Land et al. (2016). So, these studies prove that CWs represent a nature based solution highly suitable to address the restoration of eutrophic water bodies. The main difference among the cited studies is that the scale used in each case is different: full or pilot for the subsurface systems, so an issue arises: how could work a full scale horizontal subsurface flow treating eutrophic water? Another interesting issue, scarcely studied before, is how the plankton biomass and diversity changes across the CWs. In eutrophic water masses, not only removal of phytoplankton but increasing of zooplankton is an important objective to improve it trophic status towards mesotrophic, so, in what extent could the CWs contribute to this change?

This study aims to bring some clarity to these questions analyzing some of the results obtained in a two years water quality monitoring program (2014-15) in the frame of the LIFE12 ALBUFERA project. This project is focused to demonstrate how three CWs can be managed integrating multiple objectives: to reduce pollutants from an eutrophic lake, l'Albufera de Valencia, Natura 2000 site, to recover lost habitats in the natural park, improving the biodiversity both inside and outside the CWs, and making a sustainable and participatory public use.

In this paper, the main hypotheses is that the lack of light for phytoplankton photosynthesis can be obtained in the same way from a "shadow effect" by emergent vegetation in HFCWs as well as the natural darkness inside the H/V SSF-CW. The specific objectives of this study were: (1) to evaluate the removal efficiencies and removal rates of concerning pollutants; (2) to compare kinetic constants from classical k-C models; and (3) to assess the environmental impact of the CWs in the water quality of lake l'Albufera de Valencia.

So, we analyze the performance of surface and subsurface $\mathrm{CW}$ and the influence of operational conditions, and this is done evaluating three components of the total environment: water quality (physicochemical and biological variables), soil/sediment and atmospheric deposition.

\section{Material and methods}

\subsection{Study site and description of CWs}

The study sites are three CWs located in the Albufera de Valencia Natural Park (Spain), a wetland of international significance (Ramsar site since 1989) with a highly eutrophic shallow lake (l'Albufera lake, 2100 ha surface) surrounded by 14000 ha of rice fields and with a high urban pressure (Valencia metropolitan area). L'Albufera lake is an eutrophicated water mass since the late-seventies and at present annual mean $\mathrm{Chl}$ a value is about $100 \mathrm{\mu g} \mathrm{I}^{-1}$. Dissolved oxygen in l'Albufera lake shows 
a typical daily trend in eutrophic waters: oversaturation peaks in the afternoon and values close to 0 $\mathrm{mg} \mathrm{l}^{-1}$ at dawn.

The three CWs (Tancat de la Pipa, TPCW, Tancat de Milia, TMCW, and Tancat de L'Illa, TLICW) amounting to 90 ha, were former rice fields. They have different combinations of both FWFCWs (named B sector) and HSSFCW (A sector) operating at different hydraulic loads and water depths (Figure 1, Table 1). The filter bed of the HSSFCW consists of three layers from bottom to the top: compacted clay, $30 \mathrm{~cm}$ of coarse gravel $(2-4 \mathrm{~cm})$ and $10 \mathrm{~cm}$ of natural soil. This top layer is not usual in this type of CWs but it was decided to put to reduce the environmental impact because is an environmental protected area. In order to avoid the clogging by topsoil a geotextile membrane was installed between soil and gravels.

An additional feature of all the Tancats is a shallow lagoon located at the end of the system. The incoming water is eutrophic water from L'Albufera Lake and after crossing the Tancats the water is returned to the lake. The water flows from the inlet to the sector $A, B$ and finally, $C$ except in TPCW where sector $A$ does not exist. A total of five sectors $B$ and one sector $A$ has been used in this study. It should be note that L'Albufera Lake is used as reservoir by rice farmers so they decide the water level according to rice crop cycle; this management has consequences on the availability of water in CWs.

\subsection{Sample collection and analyses}

Water samples were collected every three weeks since January 2014 to December 2015. In each $\mathrm{CW}$, eight points were monitored (inlet, outlet and six inner points) from 7:00 to 10:00 GMT in summer time and 8:00 to 11:00 GMT in winter time. The water quality variables analysed are total nitrogen (TN) and dissolved inorganic nitrogen $\left(\mathrm{N}-\mathrm{NH}_{4}{ }^{+}, \mathrm{N}-\mathrm{NO}_{2}{ }^{-}\right.$and $\left.\mathrm{N}-\mathrm{NO}_{3}{ }^{-}\right)$, total phosphorus (TP) and phosphates, silica, alkalinity, organic matter (COD), TSS and total volatile solids (TVS), Chlorophyll $a$, dissolved oxygen, conductivity, $\mathrm{pH}$ and temperature. Details of sampling method and analysis procedures can be found in Martin et al. (2013). At the same time that water was collected, water velocities were gauged using a mini current meter and water levels were measured; gauging sections mainly consist of circular or rectangular sections where either pressure or free surface flow exists.

Atmospheric loads were measured collecting the rain water with a total deposition sampler. After each rain event the concentrations of physicochemical variables were measured. Dividing by the area of the sampler and the antecedent dry period, and multiplying by the volume collected, the deposition can be expressed in terms of mass per area and time.

Sediment samples were taken in B sectors every six months, with a sediment core sampler (57 $\mathrm{mm}$ inner diameter) type Beeker (Eijelkamp) and divided into two fractions for analyses (top layer 0$5 \mathrm{~cm}$; deep layer 5-20 cm). Sediment material was powdered and sieved according to the ISO standards (ISO 11464:1994) and analysed for total nitrogen (ISO 11261:1995), nitric nitrogen (ISO 14255:1998), soluble phosphorus (ISO 11263:1994), electrical conductivity (ISO 11265:1994), pH (ISO 10390:1994) and fine fraction $(<63 \mu \mathrm{m})$ was measured by wet sieving of sediment previously dispersed (ISO 11277:1998). Organic matter content was measured by loss on ignition (LOI) at 550ㄷ for 1 hour; carbonates were restored after ignition by adding ammonium carbonate. Organic carbon (OC) was determined using the Walkley-Black procedure and the degree of sediment moisture was assessed by drying the sediment at $105^{\circ} \mathrm{C}$ for 24 hours, and the results were expressed in dry weight. 
Samples of aboveground biomass were obtained in bounded surfaces $\left(0.25-1 \mathrm{~m}^{2}\right)$ in representative vegetated areas of the TLICW cells, after a visual inspection of the vegetation cover over them. Dry weight ( $\mathrm{dw}$ ) was measured by drying the plant material at $65^{\circ} \mathrm{C}$ to a constant weight (72 h). Vegetation cover was estimated as the area occupied by vegetation, considering the projection of the aboveground biomass on the ground.

\subsection{CW operation conditions, calculations and statistical analyses.}

Hydraulic Loading Rate (HLR) and water depth in B sectors were fixed from previous experiences in TPCW (Martín et al., 2013; Rodrigo et al., 2013) and according with the design of each CW. The size of different sectors, vegetation cover and hydraulic conditions such as HLR and hydraulic retention time (HRT) are specified in Table 1. Inflow from l'Albufera Lake was continuous in TPCW because it was designed to be a gravity-fed system. Inflow was intermittent in TMCW and TLICW because they were pumping-fed and the capacity of the pumps exceeded the daily fixed flow, so the pumps worked continuously only 7-9 hours per day. The pumping was by night to take advantage of low daily electricity tariffs.

In the water mass balance, evapotranspiration is an important environmental factor that tends to concentrate the dissolved substances. Data were not directly measured but taken from a close meteorological station of the regional agricultural research center (IVIA, http://riegos.ivia.es).

The inlet mass loading (IML), mass removal rates (MRR), annual mass removal efficiencies (MRE) were calculated as follows:

$$
\begin{gathered}
\operatorname{IML}\left(\mathrm{g} \mathrm{m}^{-2} \mathrm{yr}^{-1}\right)=\left(\frac{\left(\mathrm{Q}_{\text {in }} \mathrm{C}_{\text {in }}\right)+\left(\mathrm{Q}_{\mathrm{P}} \mathrm{C}_{\mathrm{P}}\right)}{\mathrm{A}}\right) \cdot 1000 \\
\operatorname{MRR}\left(\mathrm{g} \mathrm{m}^{-2} \mathrm{yr}^{-1}\right)=\left(\mathrm{IML}-\frac{\left(\left(\mathrm{Q}_{\text {in }}+\mathrm{Q}_{\mathrm{P}}-\mathrm{ET}\right) \mathrm{C}_{\text {out }}\right)}{\mathrm{A}}\right) \cdot 1000 \\
\operatorname{MRE}(\%)=\left(\frac{\mathrm{MRR}}{\mathrm{IML}}\right) \cdot 100
\end{gathered}
$$

where $Q_{\text {in }}$ is the inflow $\left(\mathrm{m}^{3} \mathrm{~d}^{-1}\right), C_{\text {in }}$ is the input concentration $\left(\mathrm{g} \mathrm{m}^{-3}\right), Q_{p}$ is the precipitation flow $\left(\mathrm{m}^{3}\right.$ $\left.\mathrm{d}^{-1}\right), \mathrm{C}_{\mathrm{p}}$ is the atmospheric deposition concentration $\left(\mathrm{g} \mathrm{m}^{-3}\right), E T$ is the evapotranspiration $\left(\mathrm{m}^{3} \mathrm{~d}^{-1}\right), \mathrm{C}_{\text {out }}$ is the output concentration $\left(\mathrm{g} \mathrm{m}^{-3}\right)$ and $A$ is the wetland area $\left(\mathrm{m}^{2}\right)$. These variables were considered constant between measurements, except precipitation, since it is highly variable in this area. The overall MRE were calculated as accumulated mass removed during studied period divided by accumulated mass input during the same period.

\section{Statistics}

Descriptive statistics like mean, maximum, minimum and standard deviations are shown in the paper. After confirming normality (Shapiro-Wilk) and homoscedasticity (Levene test), one-way ANOVA test was used, otherwise, Kruskal-Wallis nonparametric test was employed, for comparisons of results. Multiple linear regression models were performed, using the forward stepwise method, to predict nutrient mass removal rate as function of inflow concentration and hydraulic loading rate. $A$ level of $p<0.05$ was considered statistically significant in all comparisons. Analyses were performed in SPSS 15.0 for Windows (SPSS Inc. Chicago, USA). 


\section{Hydraulics}

In two years, a mean of $3.3 \mathrm{Hm}^{3} \mathrm{yr}^{-1}$ have been treated inside CWs from I'Albufera lake. It represents approximately one third of the total volume of l'Albufera lake $\left(21 \mathrm{Hm}^{3}\right)$ but only a $1 \%$ of their total inflows. Inflow control was easier in "pumped" CWs (TMCW and TLICW) than in "gravity" CW (TPCW) because of the changes in water level of l'Albufera; for example, $1 \mathrm{~cm}$ in l'Albufera level change the inflow in $600 \mathrm{~m}^{3} \mathrm{~d}^{-1}$. However, the intermittent pumping produced a discontinuity in flow between consecutive cells across the $\mathrm{CW}$ and significant daily water level changes in sector $\mathrm{A}$ (up to $15 \mathrm{~cm}$ ) and B (up to $10 \mathrm{~cm}$ ) in TMCW. Instantaneous flow rate in P4 changes between 0 and $100 / \mathrm{s}^{-1}$ at daily scale (Fig. 1). This discontinuity let it to work like vertical subsurface system in the first $15 \mathrm{~cm}$ and horizontal flow in the $30 \mathrm{~cm}$ below. Potential evapotranspiration was $1100 \mathrm{~mm} \mathrm{yr}^{-1}$ and it ranges between $1.0 \mathrm{~mm} \mathrm{~d}^{-1}$ in winter and 6 $\mathrm{mm} \mathrm{d}^{-1}$ in summer. Precipitation in the study period was $200 \mathrm{~mm} \mathrm{yr}^{-1}$, being lesser than normal (461 $\mathrm{mm}^{-1} \mathrm{y}^{1}$. The CWs suffer an important hydraulic stress and they need a minimum of $700 \mathrm{~mm} \mathrm{yr}^{-1}$. The sum of all water surfaces is $62.6 \mathrm{ha}$, so approximately a minimum of $0.44 \mathrm{Hm}^{3} \mathrm{yr}^{-1}$, a $13 \%$ of total inflow was lost by evaporation.

\section{Concentrations}

191

Input concentrations to TPCW and TMCW come directly from Albufera lake, whilst for TLICW come from a small lagoon that drains the irrigation water from rice fields. This different origin explains the differences between incoming waters: TSS, particulate COD, TP, TN and $\mathrm{Chl} a$ concentrations are higher in the two first CWs whereas soluble COD, and DIN are quite similar. With some exceptions, the concentrations of water quality at the end of CWs are, to a greater or lesser extent, lower than their inputs (Table 2). Mean TN inflow concentrations are much lower than that found in wastewaters and similar to other eutrophic environments (Dune et al. 2013), between 2.6 and $4.4 \mathrm{mg} \mathrm{N}^{-1}$, but despite of the difficulty of reducing pollutants at low concentrations, it can be reduced to values around $1.2-2.2 \mathrm{mg} \mathrm{N} \mathrm{I}^{-1}$. These values of output TN are close to those obtained by Martin et al. (2013) in TPCWs between 2009 and 2011 and it can be considered as the background concentration ( $C^{*}$ ) of TN in the treatment of eutrophicated waters that can be expected. The minimum values $0.4,0.5,0.6$, and 1 $\mathrm{mg} \mathrm{N} \mathrm{^{-1 }}$ are in the range of 0.3-0.7 $\mathrm{mg} \mathrm{N}^{-1}$ proposed in the same article for $\mathrm{C}^{*}$ in FWSCWs. Values below $0.3 \mathrm{mg} \mathrm{N} \mathrm{I}^{-1}$ have never been found. TP is the main concerning pollutant because it is the nutrient limiting in this aquatic ecosystem. All of CWs reduces TP excepting B sector in TMCW because its input concentration is close to background concentration. Dune et al. (2015) calculated temperature-dependent $C^{*}$ between 0.030 and 0.044 $\mathrm{mg} \mathrm{Pl}^{-1}$ and Martin et al. (2013) proposed a $\mathrm{C}^{*}$ value around 0.03-0.07 $\mathrm{mg} \mathrm{Pl}^{-1}$. On the other hand, Li et al. (2008) found mean effluent concentrations $0.052 \pm 0.03 \mathrm{mg} \mathrm{Pl}^{-1}$ using HSSF and $0.103 \pm 0.03 \mathrm{mg}$ $\mathrm{P}^{-1}$ using FWS. According to these results, it seems quite difficult to reduce even more TP with a FWS sector if there is a previous HSF, especially considering that this FWS sector hardly has vegetation cover. Rather, the resuspension of sediments by wind, fishes and aquatic avifauna in poorly vegetated FWSCW increases the phosphorus sorbed to TSS. In TMCW there is a strong lineal

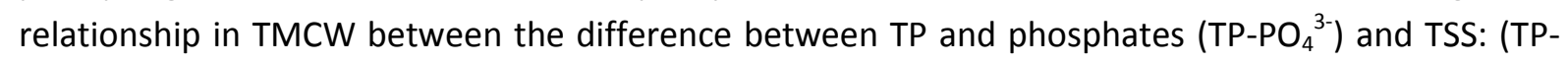


$\left.216 \mathrm{PO}_{4}{ }^{3-}\right)=0.0029 \mathrm{TSS}+0.0547\left(\mathrm{r}^{2}=0.65, \mathrm{n}=138\right)$. This expression means that an average increase of 9.2

$217 \mathrm{mg} \mathrm{TSS} \mathrm{I}{ }^{-1}$ accounts for an increase of $0.027 \mathrm{mg} \mathrm{Pl}^{-1}$ and a mean output value of $0.115 \mathrm{mg} \mathrm{Pl}^{-1}$ which

218 is quite close to mean value $0.126 \mathrm{mg} \mathrm{Pl}^{-1}(9.6 \%)$.

219 Phytoplankton, measured through the concentration of pigment $\mathrm{Chl} a$, reach input concentrations

220 higher than $200 \mu \mathrm{g} \mathrm{Chl} a \mathrm{I}^{-1}$, typical values in hypertrophic aquatic ecosystems. One of the main

221 successes is that this $C_{\text {in }}$ was reduced to mean values in the range of 15-30 $\left.\mu \mathrm{g} \mathrm{Chl} a\right|^{-1}$, but more

222 important finding is that a $59 \%$ of the values in B sectors are below $25 \mu \mathrm{g} \mathrm{Chl} a \mathrm{I}^{-1}$ which can be

223 considered as a threshold value (OCDE, 1982) between eutrophic and hypereutrophic ecosystem.

224 This represents a significant improvement because only a $6 \%$ of the values in inflow were below this

225 limit. The results in sector A were significantly better: a 77\% of the values were below $25 \mu \mathrm{g} \mathrm{Chl} a \mathrm{I}^{-1}$

226 and $34 \%$ were below $8 \mu \mathrm{g} \mathrm{Chl} a \mathrm{I}^{-1}$, limit between eutrophic and mesotrophic ecosystems. The total

227 dark conditions and the interception mechanism inside the substrate of HSSFCW are effective in

228 phytoplankton death and settling, do not depend on vegetation cover, and it is not affected by

229 climatic variables like wind nor biological disturbances by aquatic birds or fishes.

230 The main exception in reducing concentrations concerns to organic matter. Organic matter is

231 difficult to reduce in such FWSCWs by several reasons, but all of them closely related with

232 vegetation cover. For example, the increase in B-TMCW, a very poorly vegetated wetland, is

233 explained by resuspension of sediments and wildlife loads. The organic matter in sediments is about

$23425 \mathrm{~g} \mathrm{C} \mathrm{kg}^{-1}$ (Table 7), so an increase of $10 \mathrm{mg} \mathrm{l}^{-1}$ produces an increase of $0.7 \mathrm{mg} \mathrm{COD} \mathrm{l}^{-1}$. The increases

235 in B-TLICW, a highly vegetated wetland (aboveground biomass about $2 \mathrm{~kg}$ dry weight $\mathrm{m}^{-2}$ ), are due to

236 decomposition of Typha litter. As Mitsch et al. (2012) stated, constructed wetlands are carbon-fixer

237 environments, but they must be harvested to avoid the turnover of carbon and nutrients to water;

238 harvest is not so necessary in HSSFCW but is crucial in FWSCWs. The decomposition of litter

239 produces soluble COD (Álvarez and Becares, 2006; Hernández-Crespo et al. 2016) and according to

240 this, soluble COD concentration increases in vegetated CWs. Again, the A sector is the only one that

241 reduces effectively organic matter.

242 The provisional conclusion is that sector $\mathrm{A}$ is the better (in terms of physicochemical variables) and it

243 works so well that is difficult to obtain water quality improvements with surface sectors behind it.

244 However to conclude anything about what is better or poorest is mandatory to calculate efficiencies

245 in terms of mass removal because it takes into account the evapotranspiration and atmospheric

246 loads.

247

248 Mass loading and mass removal rates

249

250 The origin of mass loading to CWs is mainly water from l'Albufera but also atmospheric deposition

251 and internal loads from sediment resuspension and litter decomposition. The results of atmospheric

252 loading rates for TP, shown in Table 3, are in the high range of collected data around the world

253 (Tipping et al., 2014) and four times higher than those obtained by the authors in other CW located

254 in the urban zone of Valencia (Martin et al. 2013). This high value is explained by the closeness of

255 rice paddies with soils rich in fertilizers and the transport of dust and straw by wind. The mean

256 values do not show important differences among the three $\mathrm{CW}$ ( $p>0.05)$, but its impact was different

257 depending of the nutrient loading with inflowing water in each sector type B. In TLICW and TMCW it

258 is much lower than in TPCW, therefore the atmospheric deposition represents an important load in

259 relative terms, between 10 and $20 \%$, so it cannot be neglected in efficiencies calculations. 
Total nitrogen deposition is also in the high range of reported data because of the influence of agriculture. Phoenix et al (2006) showed a rate in the "biodiversity hot spot" Mediterranean Basin about $7 \mathrm{~kg} \mathrm{~N} \mathrm{ha}^{-1} \mathrm{yr}^{-1}$, with maximum values over 18 (1990 data) and they predict a mean value of 13 in 2050 with maximum of 24 . In this study, the obtained values ranged between 11 and $17 \mathrm{~kg} \mathrm{~N} \mathrm{ha}^{-1}$ $\mathrm{yr}^{-1}$.

Previous studies stated that the main parameters influencing the removal rate and efficiency are the input concentration, the HLR and the vegetation cover (Oliver et al. 2016). In this study, the removal efficiencies are highly variable depending on vegetation cover, HLR and input concentrations, excepting for TN (Figure 2). In the range of HLR between 9.12 and $54.75 \mathrm{~m} \mathrm{yr}^{-1}$, TN is always reduced in any CW, from a minimum of $30 \%$ to a maximum of $75 \%$. These high efficiencies are related with the high efficiencies in removal DIN: nitrification of ammonia, denitrification of nitrates and other possible mechanisms of ammonia removal are usual in CWs; and very efficient when an important fraction of TN is in inorganic form, there is carbon availability and the dissolved oxygen fluctuates over the day (Oliver et al. 2016). All of these three conditions are fulfilled in waters from l'Albufera and inside the CWs: more than $50 \%$ is DIN (70\% in TLICW inflow), there is enough carbon from plants, phytoplankton and detritus from wildlife (COD measured) and oxic and anoxic conditions occurs naturally due to the presence of algae (see maximum and minimum values of DO in Table 2). The mean value for FWSCW, 53\%, is quite similar that obtained TPCWs in the startup period 2009-11, 52\%, (Martin et al., 2013). The current results confirm that high TN removal efficiency can be expected in CW treating eutrophic waters. To maximize TN mass removal, the best option was working at high HLR; in these conditions the mass removal rates obtained were $77.71 \mathrm{~g} \mathrm{~m}^{-2} \mathrm{yr}^{-1}$ in A sector and $98.51 \mathrm{~g} \mathrm{~m}^{-2}$ $\mathrm{yr}^{-1}$ in poorly vegetated FWSCW (Figure 2). The range of removal rates obtained falls in the range of similar wetlands (Dune et al., 2013). Negative values of removal percentage mean that pollutant mass increase inside the CW, for example TP and phytoplankton increased in low vegetated sectors with low HLR $\left(<9.12 \mathrm{~m}^{3} \mathrm{~m}^{-2} \mathrm{yr}^{-1}\right.$, Fig. 2). Such low value of HLR gives rise to high HRT (around 9 days) and low vegetation density allows sunlight to reach the water surface. Both conditions are favorable to phytoplankton growth and, additionally, the phosphorus supply is enhanced by sediment resuspension. When HLR increases in such low vegetated sectors, HRT decreases, the above-mentioned processes are losing influence and the removal percentages becomes positive. In contrast, total phosphorus removal is about $40-50 \%$ in high vegetated B sectors and A sector. In both types of CWs, a downward trend is observed when HLR increases and HRT is reduced, although this decrease is only significant in $B$ sector (VC $>50 \%)$ when moving from the second to the third range of $H L R(p<0.05)$. Removal of TSS requires the presence of high vegetation cover or a subsurface flow unit, both types of CWs can provide high and similar removal efficiencies ( $p>0.05$ ). Whereas low vegetated $B$ sectors provide an efficiency significantly lower $(p<0.05)$. By sectors, the A sector is the most efficient system for all the variables when the HLR is in the upper range $\left(>18.25 \mathrm{~m}^{3} \mathrm{~m}^{-2} \mathrm{yr}^{-1}\right)$ and, consequently, is the system that can remove more quantity of pollutant per time unit. It should be pointed out that fully vegetated $B$ sector brings similar efficiency results, but at lower HLR, and also lower inlet mass loading rates (see values above the bars in Figure

301 2). Finally, A sector is the only that can ensure high removal percentages of phytoplankton, around $80 \%$, at high HLR. Removals in B sectors are lower than $55 \%$. 
304 Given that the input concentration $\left(C_{\text {in }}\right)$ and HLR have been observed to be the main influencing 305 parameters, multiple linear regression models were developed as a management tool for this type of 306 system, allowing us to know the rate of elimination of nutrients and suspended solids from these 307 parameters. An additional objective of the model development is to see if there are differences 308 between the FWSCWs and the HSSFCW. Indeed, the models obtained differ notably among the type 309 of CW (Figure 3, Table 4). In general, the models fit the data better for the A sector, as can be seen in 310 Figure 3 , with high values of $R^{2}$ coefficients (Table 4). The MRR are also higher than that obtained for 311 the $B$ sectors, except for TP which is removed at a lower rate in the subsurface sector because the $C_{\text {in }}$ 312 is low $\left(0.17 \mathrm{mg} \mathrm{L}^{-1}\right)$. This better fitting of sector $A$ is related with the fact that the performance of this 313 kind of $\mathrm{CW}$ is less affected by environmental factors such as wind or bird resuspension, obtaining a 314 lower variability in mass removal rates and barely negative values. Chlorophyll $a$ and TN depend on 315 both parameters ( $C_{\text {in }}$ and HLR) for all sectors, whereas other variables depend mainly on the $C_{\text {in }}$ 316 (Table 4). The conclusion drawn from these models is that when the $C_{\text {in }}$ is very low it is advisable to 317 work at moderate HLR from a point of view of the energy efficiency of water pumping. On the other 318 hand, when the $C_{\text {in }}$ is high the systems are more efficient and working at high HLR is advisable if it is 319 desired to eliminate a greater amount of contaminating mass. These results are in agreement with 320 what was observed by Dunne et al. (2012) and Oliver et al. (2016), so that it contributes to 321 demonstrate the behavior of the systems and to validate the recommendations proposed by 322 previous studies. Furthermore, models for new variables (chlorophyll $a$, total suspended solids and 323 chemical organic demand) have been developed, gaining insight about these variables.

324 Another approach that allows us to make useful comparisons among CWs is the calculation of the 325 first-order kinetic constants from of k-C models (Kadlec and Knight, 1996). In this case, this model is 326 of limited applicability because many times the wetlands were not sinks but sources of substances. 327 More detailed mechanistic models are being developed both in subsurface (Samsó and García, 2013) 328 and surface (Gargallo et al. 2016) to design and operate CWs, but K-C models are still interesting to 329 have a first approximation to CWs functioning. According to this, the $k_{A}$ has been calculated from 330 two data sets: the first consist by those whose output concentration is lower than input 331 concentration (named removal data); the second set includes all the data and are corrected to $20{ }^{\circ} \mathrm{C}$ 332 (Tables 5 and 6 ).

333 The results show clearly that HSSFCW $\mathrm{k}_{\mathrm{A}}$ constants are several times greater than in FWSCWs, 334 confirming that this typology is the most adequate to improve the physicochemical variables of 335 eutrophic waters.

336 Considering only the $\mathrm{k}_{\mathrm{A}}$ obtained from removal data, similar values can be observed in all FWSCWs. 337 It means that when this type of CWs reduces these pollutants, the rate is quite similar. But when 338 percentage of removal data is low (around $50 \%$ or less) the total $\mathrm{k}_{\mathrm{A}}$ is lower, reflecting the fact that 339 the CW produces this pollutant many times. It occurs mainly in low-medium vegetated surface 340 wetlands with TSS, TP, COD and $\mathrm{Chl} a$. As lower the vegetation cover is, more intense is the 341 resuspension by wind and wildlife. For example, the $k_{A}$ values for TSS increases from 10 or lower to $34220 \mathrm{~m} \mathrm{yr}^{-1}$ in highly vegetated B sectors, and almost all output values are lower than input, because 343 this the dense habitat is less suitable for "highly resuspending birds" like flamingoes, wading birds, 344 some ducks, and others. HSSFCW is not affected by these external pressures and consequently it 345 needs between 6 and 10 times less surface to obtain the same output TSS concentration.

346 This behavior, sometime source, sometimes sinks, of WQ variables in FWSCW, change when TN and 347 DIN are considered. Concentrations are reduced more than $60 \%$ of the times and the $k_{A}$ values are 348 always positive and little changes can be observed when all data or removal data were considered. It 
can be also noted that $\mathrm{k}_{\mathrm{A}}$ value in HSSF is also higher than but not as high as it was for the others variables, especially in DIN. It means that processes that reduce inorganic nitrogen are quite similar in both types of CWs and external factors are not as limiting.

A differentiated analysis must be done for COD because the removal of COD in FWSCWs in unclear (Table 6). All the CWs are able to reduce particulate COD from eutrophic waters but only subsurface systems can ensuring it at all times. Surface flow systems are sometimes source or sink of particulate COD, but from the two years data, a positive but very low $k_{A}$ value can be obtained. However, soluble COD was increased (negative $k_{A}$ values) in most free water CWs: wetlands play an important role as sinks of atmospheric carbon fixing it in the biomass, but when vegetation die and plant tissue is biodegraded, a fraction of the carbon get into water. The transfer of carbon from vegetation to water is more difficult in HSSFCW, so it is the only which reduce both particulate and soluble concentrations. The source of COD could be reduced with a harvest management plan but it is costly and consequences on biodiversity must be considered.

Another interesting finding is what happens when a FWSCW is behind an efficient HSSFCW as in TMCW: the concentrations of TSS and COD increases and the highest negative $k_{A}$ for TSS $\left(-5.8 \mathrm{~m} \mathrm{yr}^{-1}\right)$ and $\operatorname{COD}\left(-4.3 \mathrm{~m} \mathrm{yr}^{-1}\right)$ were obtained. Comparison of $k_{A}$ values in FWSCWs with obtained in previous studies in TPCW (Martin et al., 2013) shows that current values are 5-10 times lower than those obtained in 2009-2011 period. This tendency to decrease the rate has been studied before (Kadlec, 2009) and in this case it is attributed to the high efficiency in 2009-10 periods because their high density vegetation and the P-sorption process, the aging of the vegetation and the lack of harvesting between 2010 and 2015. The role of CWs in the reduction of the hypereutrophic status of l'Albufera is rather limited. As part of the project, several water quality models, not showed here, are being used to asses this impact. Nevertheless, a first approach made throughout a mass balance between inlets and outlets gives an

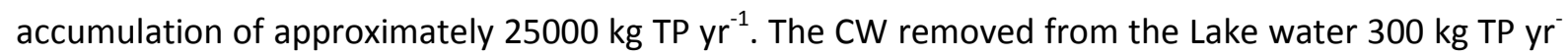
${ }^{1}$, which represents a $1.2 \%$. Therefore, the 73 ha of $\mathrm{CWs}$ by themselves are not able to recover the clear state with submerged macrophytes predominating 50 years ago, but they offer a complementary instrument to enhance the water quality and biodiversity. Nevertheless, at a local scale, inside the $\mathrm{CW}$, the improvement of water quality is quite significant and, consequently, an increase of biodiversity (phytoplankton, zooplankton and birds) has been found. In terms of their area, the $\mathrm{CW}$ removed $0.74 \mathrm{~g} \mathrm{~m}^{-2} \mathrm{yr}^{-1}$ which is very similar to the value obtained by Dunne et al. (2012).

\section{Phytoplankton and zooplankton results}

The biovolume of phytoplankton decreased from the inlet (Fig. 4, sites P1 or P3) to the outlet of the constructed wetland cells (Fig. 4, sites P6 or P7). There was a significant difference between the performance of subsurface (A) and surface (B) flow sectors, the former reducing much more the biovolume: the biovolume removal between $\mathrm{P} 1$ and $\mathrm{P} 5$ in TMCW (A sector plus a section of $\mathrm{B}$ sector) is $85 \%$ (quite similar to $\mathrm{Chl} a$ reduction in A sector), whilst between P3 and P6 in TPCW, P7 in TLICW, (B sectors) is $50 \%$ and $20 \%$, respectively. Nevertheless, the fact that surface sectors can reduce the phytoplankton biovolume, even when the inlet concentration is low (TPCW and TLICW), is a remarkable result. Sectors $C$ (shallow lagoons) behave different, likely due to different morphology or operation conditions. The lagoon with better performance was that of TMCW, with one inland 
and several areas with emergent vegetation, so less affected by wind resuspension. The lagoon of TPCW, despite having two inlands, did not contribute to the reduction of phytoplankton biovolume, surely because it operated at very low HLR $\left(0.018 \mathrm{~m}^{3} \mathrm{~m}^{-2} \mathrm{~d}^{-1}\right.$ on average) and high HRT (31 d on average), which favours its growth. Finally, the lagoon of TLICW does not have any inland to prevent wind effects, and also increased slightly the biovolume of phytoplankton. With regard to phytoplankton assemblage, two important findings are that all three systems reduced the fraction of Cyanophyceae, a group of algae with potentially toxic species (Rodrigo et al. 2013) and increased the fraction of Euglenophyceae, a group of algae able to alternate autotrophic and heterotrophic periods, based on the availability of sunlight, thus acting as consumers in the heterotrophic periods (Calero et al. 2015). The CW acted as a zooplankton nursery, increasing the concentration from the inlet to the outlet in all three CW (Fig. 4). In the case of TMCW and TLICW the highest increase is produced in the shallow lagoons (sectors $\mathrm{C}$ ). Just like in the physicochemical variables, the presence of a good coverage of vegetation is a favourable aspect, being the system with greater plant cover, the one that most zooplankton exports to the outside (TLICW). In this sense, a very important feature is the development of cladocerans, filter feeders that will play a very important role in the Albufera Lake (Calero et al. 2015). Besides this, the biggest increase usually occurs in spring, coinciding with the peaks of phytoplankton in the Albufera Lake, so that the creation of these artificial wetlands can be considered a very useful measure to limit peaks of phytoplankton.

413

\section{Sediments results}

415 Sediments characteristics of the three $\mathrm{CW}$ are presented in Table 7. The content of organic carbon is 416 high, around 2.7\%, and similar to sediments of Albufera Lake (Hernández-Crespo et al. 2013), being 417 slightly lower in TPCW (2.4\%). Sediments are also rich in total nitrogen (mean value around 2900 $418 \mathrm{mg} / \mathrm{kg}$ ) and again it is somewhat inferior in TPCW $(2700 \mathrm{mg} / \mathrm{kg})$. In contrast, the value of soluble phosphorus is high only in TPCW, reaching values of $104 \mathrm{mg} / \mathrm{kg}$ in the sector $\mathrm{B}$, the other CW have a poorer nutrient content (lower than $50 \mathrm{mg} / \mathrm{kg}$ in sectors B), maybe due to the removal of a deeper layer of agricultural soil in them. The content of nitric nitrogen is low in the three $\mathrm{CW}$, related with the anoxic conditions of sediments. According to the results of the electrical conductivity, the sediments are saline in TLICW and very saline in TPCW and TMCW. In line with other studies, the concentration of nutrients and organic matter is generally higher in the upper layer (Maine et al. 2007; Passoni et al. 2009), but in our case the difference was not significant $(p>0.05)$, around $4 \%$ for organic carbon and soluble phosphorus and $9 \%$ for total nitrogen. However, unlike these other studies, no significant increases of nutrient and organic matter contents have been observed over the study period, even in the closest sites to the inlet, likely because of the lower input concentrations in water treated in this study, joined to the fact that processes in sediments are more slow and changes are observed in a longer term period (Passoni et al. 2009). In this sense, although the concentrations of organic carbon and total nitrogen are not so evident, the $\mathrm{C} / \mathrm{N}$ ratio did present a slight tendency to increase, indicating a gradual accumulation of $\mathrm{C}$ with respect to $\mathrm{N}$. Regarding the comparison of the three CW studied, the main difference is that the sediment from TPCW presented a higher concentration of soluble phosphorus. This finding, together with the lower vegetation cover and increased sediment resuspension associated with lower water depth, helps to explain the lower performance of this sector in terms of phosphorus removal. 


\section{CONCLUSIONS}

Six constructed wetlands, five with free water surface flow and one with horizontal subsurface flow have been studied for improving eutrophic waters. The results showed that HSSFCW is faster than FWSCW reducing TSS, TP, TN, COD and phytoplankton, thus it needs less area to obtain similar output concentrations. This is the main advantage of HSSFCW with regard to FWSCW. Completely darkness condition inside the substrate was easily obtained and thus, the phytoplankton removal was very effective since the start-up, independently of vegetation growth. Suitable shadow conditions were also obtained in FWSCWs when they were highly vegetation covered but they need a bigger effort in vegetation management (protection by bird predation, for example) and it takes a long time to become fully operational. In addition, litter decomposition increases significantly total COD in effluents while HSSFCWs always reduce it. These results allow us to recommend working FWSCWs between 18 and $27 \mathrm{~m} \mathrm{yr}^{-1}$, and HSSFCW at $55 \mathrm{~m} \mathrm{yr}^{-1}$. The biological enhancement in terms of zooplankton biomass, a key variable in restoration of eutrophic waters, is best achieved in well vegetated surface systems like FWSCW and shallow lagoons. Again, high cover vegetation is mandatory. Accordingly with these results, the recommendation for the implementation of CWs in natural sites to reduce phytoplankton from waters is a first step with a HSSFCW to reduce physicochemical variables following a FWSCW to increase the zooplankton biomass.

In large-scale CWs, treating eutrophic water, the inlet loads associated with atmospheric deposition should be considered, since they can represent an important percentage of total loads.

The development of multiple linear regression models has represented a simple and useful tool to manage and design CWs treating eutrophic waters, especially in the case of HSSFCW for which the goodness of fit has been especially good.

\section{ACKNOWLEDGEMENTS}

The authors would like to acknowledge the financial support of LIFE program of CE to the project LIFE12/ENV/ES/000685 ALBUFERA, Confederación Hidrográfica del Júcar, Aguas de las Cuencas Mediterráneas and the Spanish Fundación Biodiversidad (Ministry of Agriculture, Food and Environment).

\section{REFERENCES}

Álvarez, J.A., Bécares, E., 2006. Seasonal decomposition of Typha latifolia in a free-water surface constructed wetland. Ecol. Eng. 28, 99-105.

Calero, S., Segura, M., Rojo, C., Rodrigo, M.A. 2015. Shifts in plankton assemblages promoted by free wáter Surface constructed wetlands and their implications in eutrophication remediation. Ecol. Eng. 74, 385-393.

Dunne, E.J., Coveney, M.F., Marzolf, E.R., Hoge, V.R., Conrow, R., Naleway, R., 2012. Efficacy of a large-scale constructed wetland to remove phosphorus and suspended solids from lake Apopka, Florida. Ecol. Eng. 42, 90-100.

Dunne, E.J., Coveney, M.F., Marzolf, E.R., Hoge, V.R., Conrow, R., Naleway, R., Lowe, E.F., Battoe, L.E., Inglett, P.W., 2013. Nitrogen dynamics of a large-scale constructed wetland used to remove 
Dunne, E.J., Coveney, M.F., Hoge, V.R., Conrow, R., Naleway, R., Lowe, E.F., Battoe, L.E., Wang, Y., 2015. Phosphorus removal performance of a large-scale constructed treatment wetland receiving eutrophic lake water. Ecol. Eng. 79, 132-142.

Gargallo, S., Martín, M., Oliver, N., Hernández-Crespo, C., 2016. Sedimentation and resuspension modelling in free water surface constructed wetlands. Ecol. Eng. 98, 318-329. http://dx.doi.org/10.1016/j.ecoleng.2016.09.014.

Hernández-Crespo, C., Martín, M., 2013. Mid-term variation of vertical distribution of Acid Volatile Sulphide and Simultaneously Extracted Metals in sediment cores from Lake Albufera (Valencia, Spain). Arch. Environ. Contam. Toxicol. 65, 654-664.

Hernández-Crespo, C., Oliver, N., Bixquert, J., Gargallo, S., Martín, M., 2016. Comparison of three plants in a surface flow constructed wetland treating eutrophic water in a Mediterranean climate. Hydrobiologia 774, 183-192.

Kadlec, R.H., 2009. Wastewater treatment at the Houghton Lake wetland: Hydrology and water quality. Ecol. Eng. 35, 1287-1311.

Kadlec, R.H. and Knight, R.L. 1996. Treatment Wetlands. CRC Press Boca Raton, Florida. 893 p.

Land, M., Granéli, W., Grimvall, A., Hoffman, C.C., Mitsch, W.J., Tonderski, K.S., Verhoeven, J.T.A., 2016. How effective are created or restored freshwater wetlands for nitrogen and phosphorus removal? A systematic review. Environ. Evid. 5, 9. DOI 10.1186/s13750-016-0060-0.

Li L., Li, Y., Biswas, D. K., Nian, Y., Jiang, G., 2008. Potential of constructed wetlands in treating the eutrophic water: evidence from Taihu Lake of China. Bioresource Technol. 99, 1656-1663.

Maine, M.A., Suñe, N., Hadad, H., Sánchez, G., 2007. Temporal and spatial variation of phosphate distribution in the sediment of a free water surface constructed wetland. Sci. Tot. Env. 380, 7583.

Martín, M., Oliver, N., Hernández-Crespo, C., Gargallo, S., Regidor, M.C., 2013. The use of free water surface constructed wetland to treat the eutrophicated waters of lake L'Albufera de Valencia (Spain). Ecol. Eng. 50, 52-61.

Martín, M., Gargallo, S., Hernández-Crespo, C., Oliver, N., 2013. Phosphorus and nitrogen removal from tertiary treated urbanwastewaters by a vertical flow constructed wetland. Ecol. Eng. 61, 3442.

Mitsch, J.W., Bernal, B., Nahlik, A.M., Mander, U., Zhang, L., Anderson, C.J., Jørgensen, S.E., Brix, H., 2013. Wetlands, carbon and climate change. Landsc. Ecol. 28, 583-597

Oliver, N., Martín, M., Gargallo, S., Hernández-Crespo, C., 2016. Influence of operational parameters on nutrient removal from eutrophic water in a constructed wetland. Hydrobiologia, DOI 10.1007/s10750-016-3048-4

Passoni, M., Morari, F., Salvato, M., Borin M., 2009. Medium-term evolution of soil properties in a constructed surface flow wetland with fluctuating hydroperiod in North Itlay. Desalination 246, 215-225.

Phoenix, G.K., Kevin Hicks, W., Cinderby,S., Kuylenstierna, J.C.I, Stock,W.D., Dentener,F.J., Giller,K.E., Amy, A.T., Lefroy,R.D.B., Gimeno,B.S., Ashmore,M.R., Ineson,P., 2006. Atmospheric nitrogen deposition in world biodiversity hotspots: the need for a greater global perspective in assessing $\mathrm{N}$ deposition impacts. Glob. Chang. Biol. 12, 470-476. Doi: 10.1111/j.1365-2486.2006.01104.x

Rodrigo, M.A., Martín, M., Rojo, C., Gargallo, S., Segura, M., Oliver, N., 2013. The role of eutrophication reduction of two small man-made Mediterranean lagoons in the context of a broader remediation system: Effects on water quality and plankton contribution. Ecol. Eng. 61, 371-382.

Samsó, R., Garcia, J., 2013. BIO_PORE, a mathematical model to simulate biofilm growth and water quality improvement in porous media: application and calibration for constructed wetlands. Ecol. Eng. 54, 116-127

Tipping, E., Benham, S., Boyle, J. F., Crow, P., Davies, J., Fischer, U., Guyatt, H., Helliwell, R., JacksonBlake, L., Lawlor, A. J., Monteith, D. T., Rowe E. C., Toberman, H., 2014. Atmospheric deposition 
of phosphorus to land and freshwater. Environ. Sci. Process. Impacts. DOI: 10.1039/c3em00641g. 536 Vymazal, J., Kropfelova, L., (2008). Wastewater Treatment in Constructed Wetlands with Horizontal Sub-surface Flow. Springer Verlag. 
541 Figure 1. Location of Lake Albufera and Constructed Wetlands (TPCW, TMCW, TLICW).

542

543

544

545

546

547

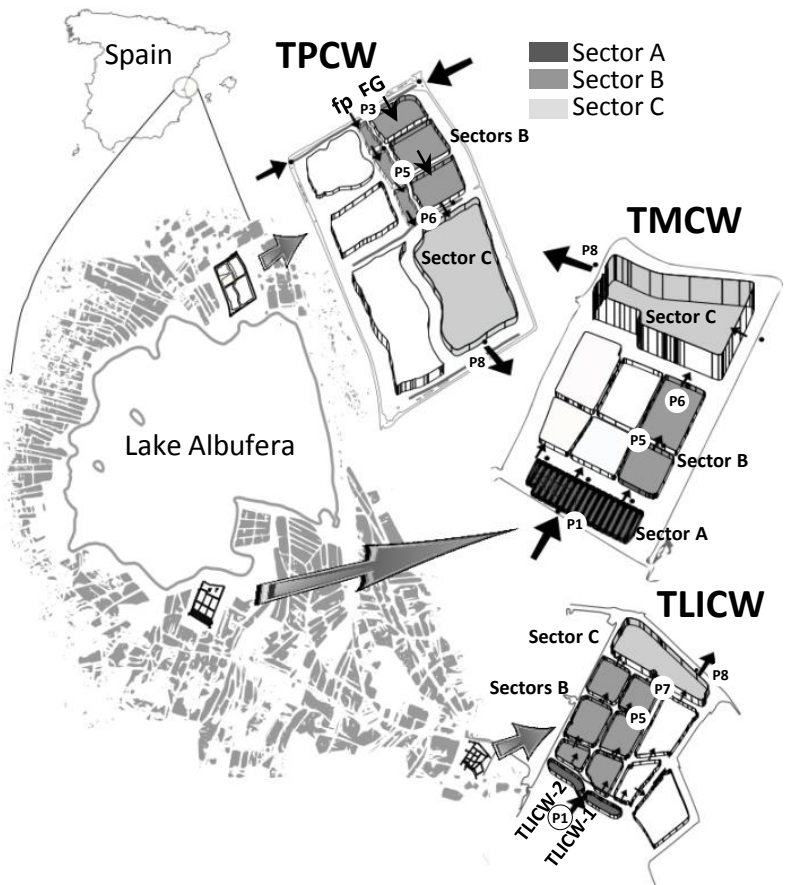

Figure 2. Removal efficiencies for different ranges of HLR (X-axis) and type of CW (VC>50\%: surface with vegetation cover higher than $50 \%$; $V C<50 \%$ : surface with vegetation cover lower than $50 \%$; $A$ : subsurface flow). The values over the bars are the mean inlet mass loading rates $\left(\mathrm{g} \mathrm{m}^{-2} \mathrm{yr}^{-1}\right)$. ND: nonexistent data.
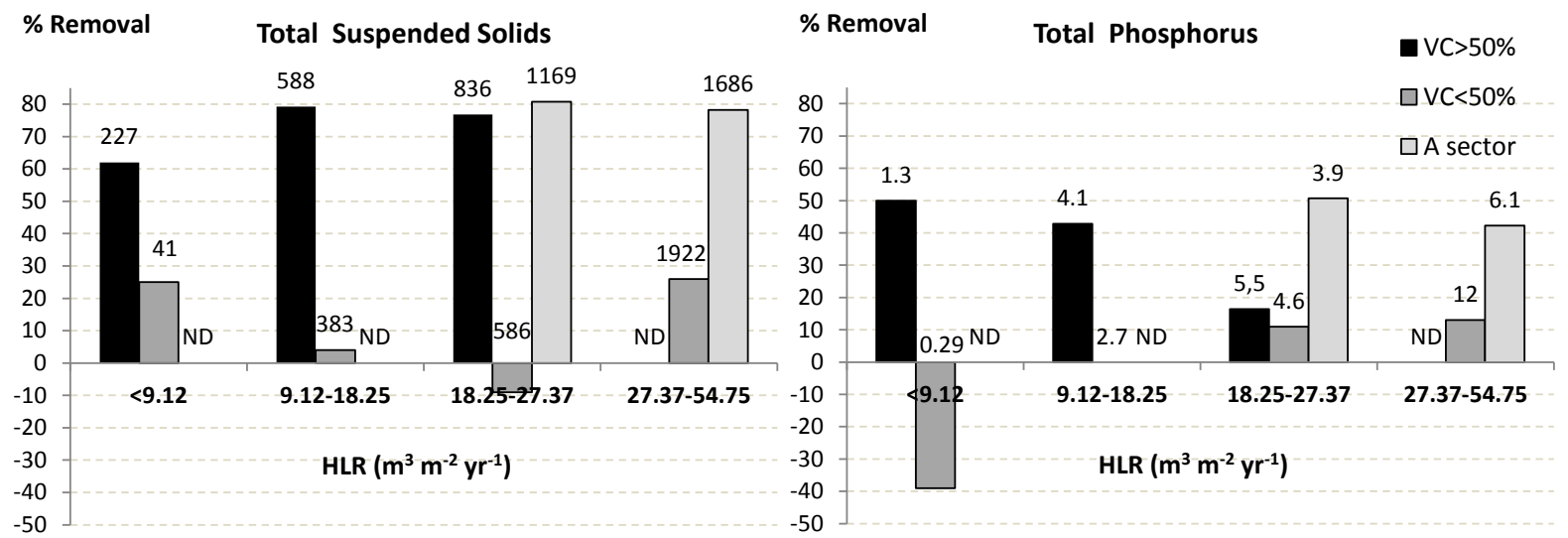

\% Removal Total Nitrogen

\% Removal Chlorophyll a
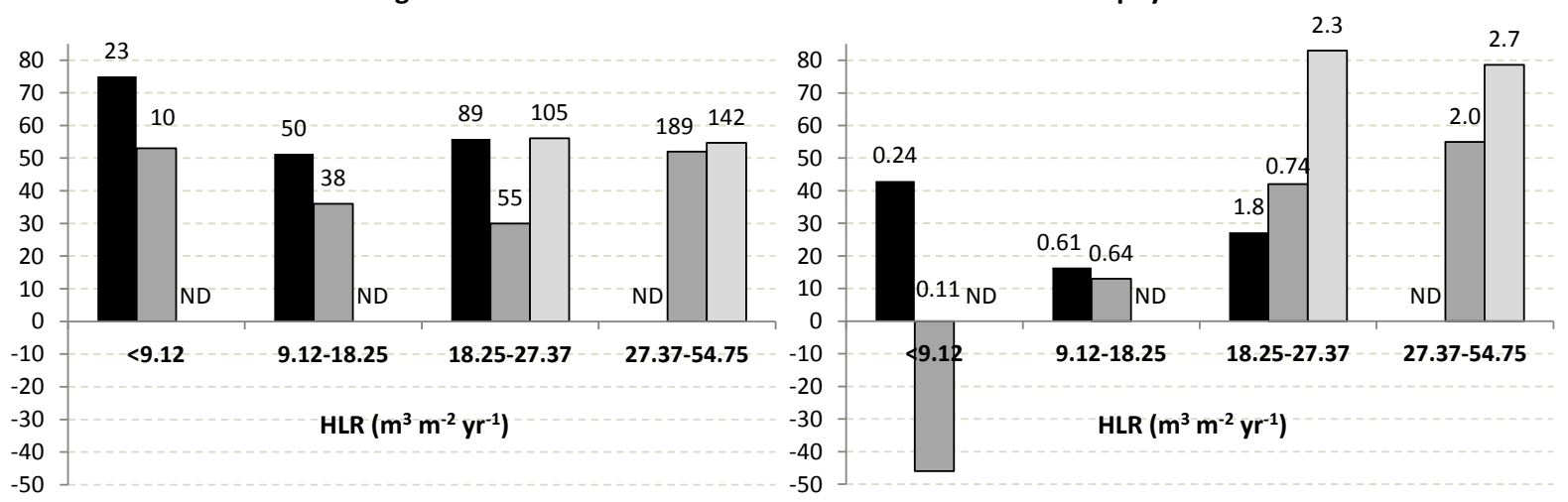
550 Figure 3. Relative cumulative frequency of Mass removal rates for different types of CW: Sector A: subsurface are displayed as markers and the corresponding multiple linear regression models (MLR) are shown as lines.
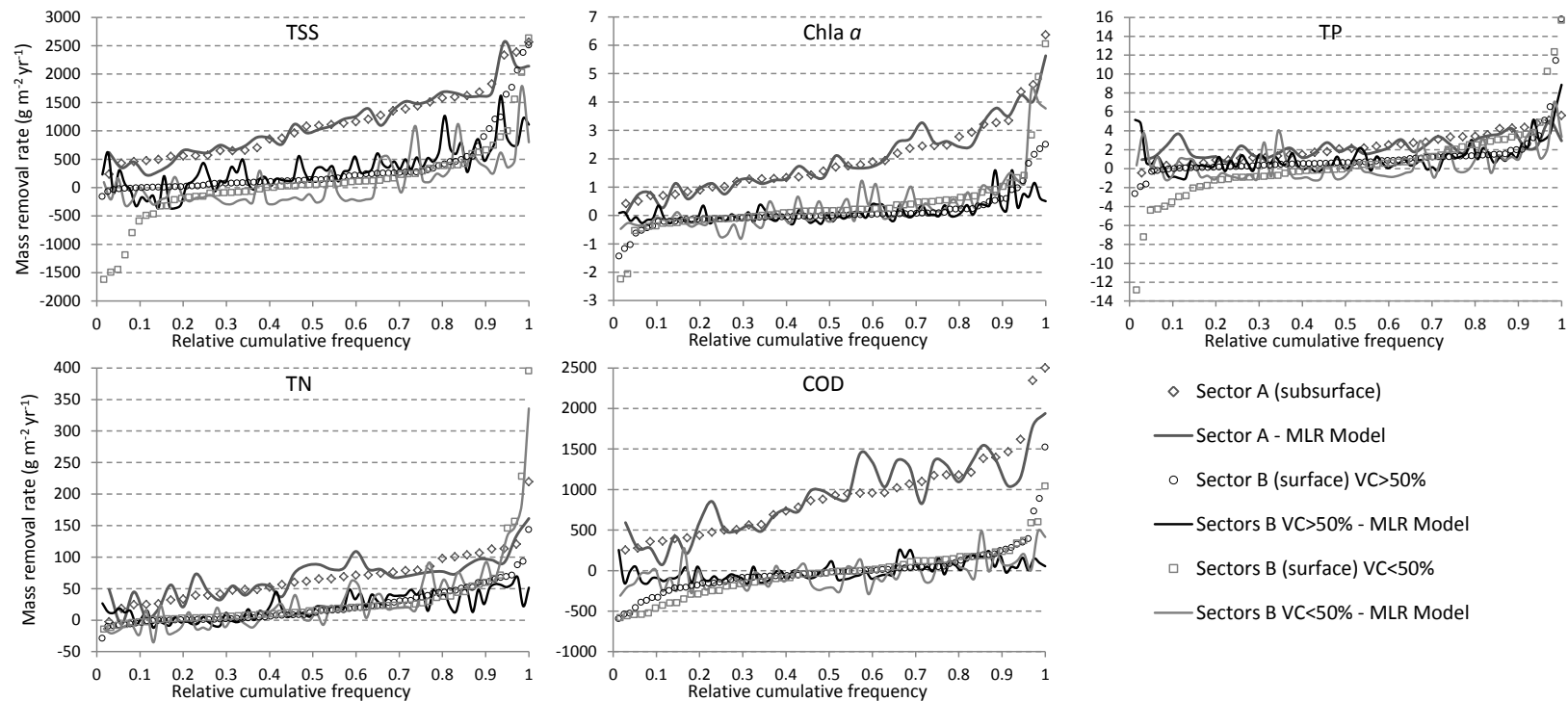

- Sector A (subsurface)

- Sector A - MLR Model

- Sector B (surface) VC $>50 \%$

- Sectors B VC $>50 \%$ - MLR Model

口 Sectors B (surface) $V C<50 \%$

- Sectors B VC $<50 \%$ - MLR Model

Figure 4. Mean values of phytoplankton biovolume and zooplankton biomass in different sites along the CW

557 (biomass is expressed as dry mass).
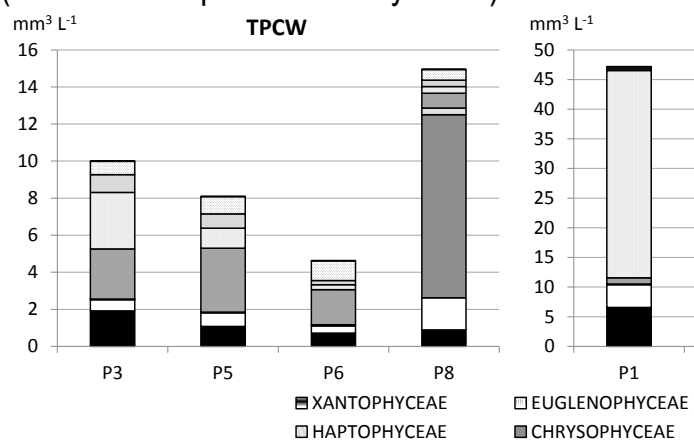

TMCW
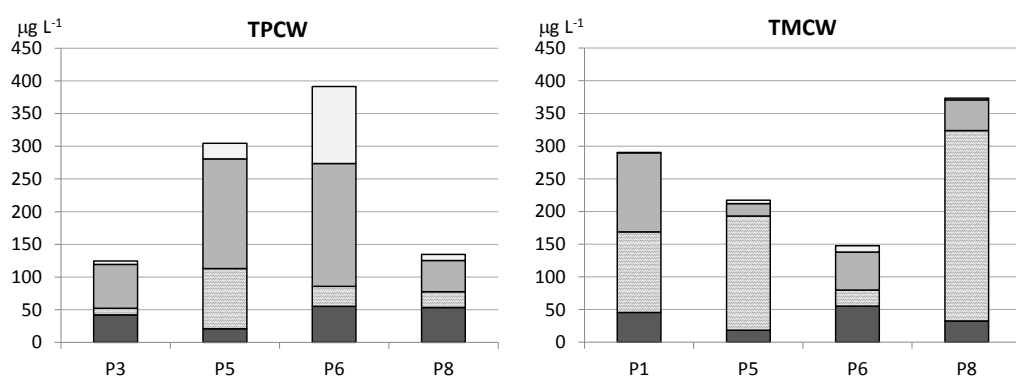

$\square$ OSTRACODA $\square$ COPEPODA $\square$ CLADOCERA $\square$ ROTIFERA

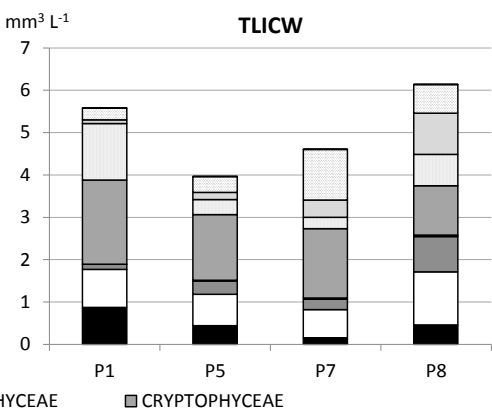

DCYANOPHYCEAE BACILLARIOPHYCEAE

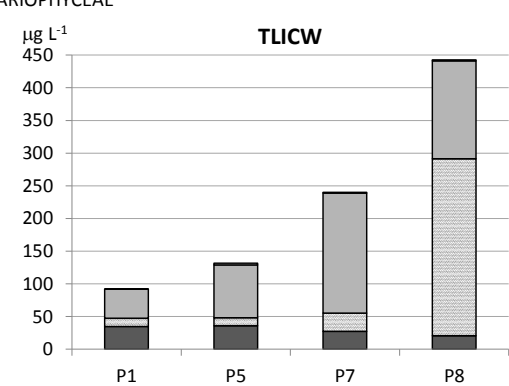


Table 1. Dimensions and operating conditions of the different sectors of $\mathrm{CW}$.

\begin{tabular}{|c|c|c|c|c|c|c|}
\hline & \multirow[t]{2}{*}{$\begin{array}{l}\text { Sector A } \\
\text { (TMCW) }\end{array}$} & \multirow[t]{2}{*}{$\begin{array}{l}\text { Sector B } \\
\text { (TMCW) }\end{array}$} & \multicolumn{2}{|c|}{$\begin{array}{l}\text { Sector B } \\
\text { (TPCW) }\end{array}$} & \multicolumn{2}{|c|}{$\begin{array}{l}\text { Sector B } \\
\text { (TLICW) }\end{array}$} \\
\hline & & & $\mathrm{fp}$ & $\overline{F G}$ & & \\
\hline Surface (ha) & 4.13 & 4.80 & 1.46 & 4.90 & 2.60 & 2.52 \\
\hline Maximum depth (m) & 0.6 & 0.4 & 0.3 & 0.3 & 0.5 & 0.5 \\
\hline Working depth (m) & 0.5 & 0.3 & 0.2 & 0.2 & 0.48 & 0.55 \\
\hline Depth oscillations (m) & $0.35-0.5$ & $0.25-0.4$ & $0.15-0.25$ & $0.15-0.25$ & $0.45-0.55$ & $0.50-0.55$ \\
\hline HLR fixed $\left(m \cdot d^{-1}\right)$ & & 0.06 & 0.06 & 0.06 & 0.06 & 0.015 \\
\hline HLR real $\left(m \cdot d^{-1}\right)$ & & 0.048 & 0.08 & 0.03 & 0.033 & 0.024 \\
\hline HRT fxed (d) & 3 & 7.9 & 3.3 & 3.3 & 6.7 & 25.9 \\
\hline HRT real (d) & 1.9 & 7.1 & 2.3 & 9.3 & 14.6 & 23.3 \\
\hline Vegetation type & Phragmites australis & Thypa angustifolia & Mixed population & Mixed population & Thypa angustifolia & Thypa angustifolia \\
\hline Vegetation cover & High & Low & Low & High & $\begin{array}{c}\text { High } \\
\left(2.3 \mathrm{~kg}-\mathrm{dw} \mathrm{m}^{-2}\right)\end{array}$ & $\begin{array}{c}\text { High } \\
\left(1.8 \mathrm{~kg}-\mathrm{dw} \mathrm{m}^{-2}\right)\end{array}$ \\
\hline
\end{tabular}

562

563 Table 2. Input and Output concentrations in 2014-15 period (mean value, $n=37$ ) in subsurface flow (Sector $A$ ) 564 and surface flow (Sectors B) constructed wetlands. TPCW and TLICW have $2 \mathrm{~B}$ sectors each. Units are $565 \quad \mathrm{mg} \mathrm{L}^{-1}$ for TSS and COD, $\mathrm{mg} \mathrm{P} \mathrm{L}^{-1}, \mathrm{mg} \mathrm{N} \mathrm{L}^{-1}$ and $\mu \mathrm{g} \mathrm{Chl} \mathrm{a} \mathrm{L-1.}$

\begin{tabular}{|c|c|c|c|c|c|c|c|c|c|c|}
\hline \multirow[t]{2}{*}{$\begin{array}{c}\text { WQ } \\
\text { variable }\end{array}$} & \multicolumn{2}{|c|}{$\begin{array}{l}\text { Sector A } \\
(\mathrm{TMCW})\end{array}$} & \multicolumn{2}{|c|}{$\begin{array}{l}\text { Sector B } \\
\text { (TMCW) }\end{array}$} & \multicolumn{3}{|c|}{$\begin{array}{l}\text { Sector B } \\
\text { (TPCW) }\end{array}$} & \multicolumn{3}{|c|}{$\begin{array}{l}\text { Sector B } \\
\text { (TLICW) }\end{array}$} \\
\hline & IN & OUT & IN & OUT & IN & OUT fp & OUT FG & IN & OUT-1 & OUT-2 \\
\hline TSS & $\begin{array}{c}50.4 \\
(19.3-102.7)\end{array}$ & $\begin{array}{c}10.1 \\
(16.7-64.0)\end{array}$ & $\begin{array}{c}10.1 \\
(16.7-64.0)\end{array}$ & $\begin{array}{c}19.3 \\
(3.2-95.2)\end{array}$ & $\begin{array}{c}50.0 \\
(23.0-136.5)\end{array}$ & $\begin{array}{c}40.4 \\
(12.8-114.0)\end{array}$ & $\begin{array}{c}8.2 \\
(3.8-14.6)\end{array}$ & $\begin{array}{c}23.6 \\
(4.2-72.4)\end{array}$ & $\begin{array}{c}7.5 \\
(1.6-29.7)\end{array}$ & $\begin{array}{c}19.0 \\
(2.6-48.7)\end{array}$ \\
\hline TP & $\begin{array}{c}0.17 \\
(0.08-0.33)\end{array}$ & $\begin{array}{c}0.088 \\
(0.035-0.233)\end{array}$ & $\begin{array}{c}0.088 \\
(0.035-0.233)\end{array}$ & $\begin{array}{c}0.126 \\
(0.051-0.464)\end{array}$ & $\begin{array}{c}0.337 \\
(0.180-0.798)\end{array}$ & $\begin{array}{c}0.300 \\
(0.108-0.641)\end{array}$ & $\begin{array}{c}0.262 \\
(0.153-0.468)\end{array}$ & $\begin{array}{c}0.122 \\
(0.032-0.246)\end{array}$ & $\begin{array}{c}0.076 \\
(0.022-0.349)\end{array}$ & $\begin{array}{c}0.088 \\
(0.028-0.186)\end{array}$ \\
\hline $\mathrm{TN}$ & $\begin{array}{c}4.4 \\
(1.5-8.3)\end{array}$ & $\begin{array}{c}2.1 \\
(1.0-4.7)\end{array}$ & $\begin{array}{c}2.1 \\
(1.0-4.7)\end{array}$ & $\begin{array}{c}1.6 \\
(0.8-2.7)\end{array}$ & $\begin{array}{c}3.5 \\
(1.6-13.5)\end{array}$ & $\begin{array}{c}2.2 \\
(1.2-3.4)\end{array}$ & $\begin{array}{c}1.3 \\
(0.5-3.4)\end{array}$ & $\begin{array}{c}2.6 \\
(0.6-6.0)\end{array}$ & $\begin{array}{c}1.2 \\
(0.4-2.6)\end{array}$ & $\begin{array}{c}1.2 \\
(0.6-2.1)\end{array}$ \\
\hline DIN & $\begin{array}{c}2.27 \\
(0.15-12.66)\end{array}$ & $\begin{array}{c}1.10 \\
(0.13-5.16)\end{array}$ & $\begin{array}{c}1.10 \\
(0.13-5.16)\end{array}$ & $\begin{array}{c}0.47 \\
(0.02-2.08)\end{array}$ & $\begin{array}{c}2.07 \\
(0.13-13.93)\end{array}$ & $\begin{array}{c}0.92 \\
(0.18-2.97)\end{array}$ & $\begin{array}{c}0.51 \\
(0.17-1.63)\end{array}$ & $\begin{array}{c}1.83 \\
(0.13-6.6)\end{array}$ & $\begin{array}{c}0.29 \\
(0.12-1.42)\end{array}$ & $\begin{array}{c}0.25 \\
(0.12-0.28)\end{array}$ \\
\hline $\mathrm{NH}_{4}{ }^{+}$ & $\begin{array}{c}0.24 \\
(0.04-1.72)\end{array}$ & $\begin{array}{c}0.21 \\
(0.03-1.76)\end{array}$ & $\begin{array}{c}0.21 \\
(0.03-1.76)\end{array}$ & $\begin{array}{c}0.16 \\
(0.01-0.98)\end{array}$ & $\begin{array}{c}0.41 \\
(0.02-1.94)\end{array}$ & $\begin{array}{c}0.41 \\
(0.02-1.67)\end{array}$ & $\begin{array}{c}0.09 \\
(0.06-0.12)\end{array}$ & $\begin{array}{c}0.26 \\
(0.03-1.61)\end{array}$ & $\begin{array}{c}0.08 \\
(0.02-021)\end{array}$ & $\begin{array}{c}0.07 \\
(0.01-0.16)\end{array}$ \\
\hline COD & $\begin{array}{c}65.4 \\
(27.6-108.0)\end{array}$ & $\begin{array}{c}33.3 \\
(16.7-64.0)\end{array}$ & $\begin{array}{c}33.3 \\
(16.7-64.0)\end{array}$ & $\begin{array}{c}45.1 \\
(21.8-77.0)\end{array}$ & $\begin{array}{c}45.2 \\
(21.9-81.0)\end{array}$ & $\begin{array}{c}43.8 \\
(26.0-77.0)\end{array}$ & $\begin{array}{c}42.6 \\
(25.3-85.0)\end{array}$ & $\begin{array}{c}29.9 \\
(11.4-64.0)\end{array}$ & $\begin{array}{c}39.4 \\
(19.7-82.0)\end{array}$ & $\begin{array}{c}38.9 \\
(20.6-62.0)\end{array}$ \\
\hline $\mathrm{COD}_{\text {sol }}$ & $\begin{array}{c}24.7 \\
(5.0-45.0)\end{array}$ & $\begin{array}{c}22.2 \\
(5.0-34.9)\end{array}$ & $\begin{array}{c}22.2 \\
(5.0-34.9)\end{array}$ & $\begin{array}{c}35.4 \\
(16.3-70.0)\end{array}$ & $\begin{array}{c}29.5 \\
(16.0-54.5)\end{array}$ & $\begin{array}{c}31.1 \\
(17.0-54.1)\end{array}$ & $\begin{array}{c}34.3 \\
(20.6-82.0)\end{array}$ & $\begin{array}{c}22.9 \\
(8.7-62.0)\end{array}$ & $\begin{array}{c}32.3 \\
(15.0-69.0)\end{array}$ & $\begin{array}{c}31.3 \\
(17.9-57.0)\end{array}$ \\
\hline Chl a & $\begin{array}{c}90.1 \\
(17.7-241.6)\end{array}$ & $\begin{array}{c}14.7 \\
(1.5-38.1)\end{array}$ & $\begin{array}{c}14.7 \\
(1.5-38.1)\end{array}$ & $\begin{array}{c}22.1 \\
(0.5-175.9)\end{array}$ & $\begin{array}{c}61.5 \\
(12.8-286.9)\end{array}$ & $\begin{array}{c}33.7 \\
(2.4-109.8)\end{array}$ & $\begin{array}{c}21.7 \\
(5.3-61.3)\end{array}$ & $\begin{array}{c}22.7 \\
(0.1-120.8)\end{array}$ & $\begin{array}{c}27.2 \\
(4.1-153.6)\end{array}$ & $\begin{array}{c}26.6 \\
(3.7-67.3)\end{array}$ \\
\hline DO & $\begin{array}{c}9.6 \\
(4.7-13.4)\end{array}$ & $\begin{array}{c}3.0 \\
(0.9-7.28)\end{array}$ & $\begin{array}{c}3.0 \\
(0.9-7.28)\end{array}$ & $\begin{array}{c}6.3 \\
(0.7-16.8)\end{array}$ & $\begin{array}{c}5.9 \\
(2.0-14.0)\end{array}$ & $\begin{array}{c}5.1 \\
(1.0-12.4)\end{array}$ & $\begin{array}{c}4.2 \\
(2.6-7.8)\end{array}$ & $\begin{array}{c}7.3 \\
(3.4-11.6)\end{array}$ & $\begin{array}{c}3.6 \\
(0.4-8.6)\end{array}$ & $\begin{array}{c}5.5 \\
(1.6-13.0)\end{array}$ \\
\hline Temp & $\begin{array}{c}18.4 \\
(7.6-30.0)\end{array}$ & $\begin{array}{c}18.3 \\
(8.2-29.4)\end{array}$ & $\begin{array}{c}18.3 \\
(8.2-29.4)\end{array}$ & $\begin{array}{c}17.6 \\
(5.9-29.2)\end{array}$ & $\begin{array}{c}18.4 \\
(6.2-29.3)\end{array}$ & $\begin{array}{c}16.9 \\
(5.1-28.9)\end{array}$ & $\begin{array}{r}16.9 \\
(5.1-28.9)\end{array}$ & $\begin{array}{c}19.5 \\
(8.5-29.4)\end{array}$ & $\begin{array}{c}18.0 \\
(7.8-29.1)\end{array}$ & $\begin{array}{c}19.3 \\
(8.6-31.0)\end{array}$ \\
\hline
\end{tabular}

Table 3. Atmospheric deposition loading rates, in $\mathrm{g} \mathrm{m}^{-2} \mathrm{yr}^{-1}$. NVSS: non-volatile suspended solids.

\begin{tabular}{|c|c|c|c|c|c|c|}
\hline & \multicolumn{2}{|r|}{ TPCW } & \multicolumn{2}{|r|}{ TMCW } & \multicolumn{2}{|r|}{ TLICW } \\
\hline & Mean & $\pm S D(n=19)$ & Mean & $\pm S D(n=17)$ & Mean & $\pm S D(n=16)$ \\
\hline $\mathrm{TP}$ & 0.16 & \pm 0.15 & 0.15 & \pm 0.16 & 0.11 & \pm 0.12 \\
\hline TN & 1.10 & \pm 0.93 & 1.68 & \pm 1.36 & 1.11 & \pm 1.02 \\
\hline NVSS & 6.94 & \pm 11.05 & 5.82 & \pm 12.24 & 8.26 & \pm 8.30 \\
\hline
\end{tabular}


Table 4. Coefficients of multiple linear regression models obtained for mass removal rates (MRR, $\mathrm{g} \mathrm{m}^{-2} \mathrm{yr}^{-1}$ ) in different types of CW (A: subsurface flow, B: free surface flow with Vegetation Cover $(\mathrm{CV})>50 \%(\mathrm{VC} \uparrow$ ) and $<50 \%(V C \downarrow))$. Equation is MRR $=a \cdot C_{\text {in }}+b \cdot H L R+c$. All the models presented $p<0.001$.

\begin{tabular}{|c|c|c|c|c|c|}
\hline & & a & $b$ & C & $\mathrm{R}^{2}$ \\
\hline & A & 25.66 & 37.35 & -1227.7 & 0.93 \\
\hline \multirow[t]{3}{*}{ TSS } & $\mathrm{B}(\mathrm{VC} \uparrow)$ & 22.58 & 29.34 & -554.5 & 0.49 \\
\hline & $B(V C \downarrow)$ & 15.71 & - & -355.9 & 0.37 \\
\hline & $A$ & 24.24 & 56.64 & -1758.6 & 0.94 \\
\hline \multirow[t]{3}{*}{ Chla } & $\mathrm{B}(\mathrm{VC} \uparrow)$ & 15.67 & - & -295.9 & 0.35 \\
\hline & $B(V C \downarrow)$ & 17.16 & 32.61 & -972.9 & 0.74 \\
\hline & A & 16.89 & - & -0.6 & 0.41 \\
\hline \multirow[t]{3}{*}{$\mathrm{TP}$} & $\mathrm{B}(\mathrm{VC} \uparrow)$ & 18.96 & - & -1.6 & 0.47 \\
\hline & $B(V C \downarrow)$ & 10.90 & - & -1.6 & 0.18 \\
\hline & A & 21.85 & 2.53 & -99.4 & 0.70 \\
\hline \multirow[t]{3}{*}{ TN } & $\mathrm{B}(\mathrm{VC} \uparrow)$ & 11.14 & 1.51 & -23.3 & 0.49 \\
\hline & $B(V C \downarrow)$ & 26.98 & 1.16 & -70.9 & 0.89 \\
\hline & $A$ & 20.64 & 19.68 & -964.8 & 0.76 \\
\hline \multirow[t]{2}{*}{ COD } & $\mathrm{B}(\mathrm{VC} \uparrow)$ & 7.92 & - & -251.9 & 0.15 \\
\hline & $\mathrm{B}(\mathrm{VC} \downarrow)$ & 12.42 & - & -516.6 & 0.35 \\
\hline
\end{tabular}

579

580 Table 5. Areal first order kinetic constants $\left(\mathrm{k}_{\mathrm{A}}, \mathrm{m} \mathrm{y}^{-1}\right)$ for some water quality variables. Values in parenthesis are 581 $\%$ of removal data. In bold, $\mathrm{k}_{\mathrm{A}}$ calculated with the complete dataset.

\begin{tabular}{|c|c|c|c|c|c|c|}
\hline & HSSFCW & $\begin{array}{l}\text { FWSCWs high } \\
\text { vegetated }\end{array}$ & & $\begin{array}{c}\text { FWSCWs } \\
\text { medium }\end{array}$ & & $\begin{array}{c}\text { FWSCWs low } \\
\text { vegetated }\end{array}$ \\
\hline Variable & $\begin{array}{l}\text { Sector A } \\
\text { (TMCW) }\end{array}$ & $\begin{array}{c}\text { Sector B } \\
(\text { TLICW-1) }\end{array}$ & $\begin{array}{c}\text { Sector B } \\
\text { (TPCW-FG) }\end{array}$ & $\begin{array}{c}\text { Sector B } \\
\text { (TLICW-2) }\end{array}$ & $\begin{array}{l}\text { Sector B } \\
\text { (TMCW) }\end{array}$ & $\begin{array}{c}\text { Sector B } \\
\text { (TPCW-fp) }\end{array}$ \\
\hline TSS & $\begin{array}{c}118.6(100 \%) \\
127.4\end{array}$ & $\begin{array}{c}23.2(86 \%) \\
11.6\end{array}$ & $\begin{array}{c}19.7(100 \%) \\
19.7\end{array}$ & $\begin{array}{c}2.6(57 \%) \\
-0.7\end{array}$ & $\begin{array}{c}8.2(46 \%) \\
-5.8\end{array}$ & $\begin{array}{c}10.4(77 \%) \\
10.4\end{array}$ \\
\hline TP & $\begin{array}{l}36.5(91 \%,) \\
\quad 36.5\end{array}$ & $\begin{array}{c}7.0(86 \%) \\
7.0\end{array}$ & $\begin{array}{c}4.2(78 \%) \\
3.0\end{array}$ & $\begin{array}{c}3.4(79 \%) \\
1.5\end{array}$ & $\begin{array}{c}7.1(40 \%) \\
-2.19\end{array}$ & $\begin{array}{c}9.9(58 \%) \\
3.3\end{array}$ \\
\hline TN & $\begin{array}{c}62.0(97 \%) \\
63.9\end{array}$ & $\begin{array}{c}19.3(68 \%) \\
8.8\end{array}$ & $\begin{array}{c}10.2(78 \%) \\
10.2\end{array}$ & $\begin{array}{c}11.2(65 \%) \\
3.9\end{array}$ & $\begin{array}{c}6.1(60 \%) \\
1.9\end{array}$ & $\begin{array}{c}10.4(88 \%) \\
9.9\end{array}$ \\
\hline DIN & $\begin{array}{c}69.3(97 \%) \\
69.3\end{array}$ & $\begin{array}{c}28.0(88 \%) \\
25.4\end{array}$ & $\begin{array}{c}14.1(67 \%) \\
6.4\end{array}$ & $\begin{array}{c}11.2(79 \%) \\
12.1\end{array}$ & $\begin{array}{c}15.3(86 \%) \\
14.2\end{array}$ & $\begin{array}{c}19.7(96 \%) \\
20.3\end{array}$ \\
\hline Chl a & $\begin{array}{c}110.7(100 \%) \\
110.7\end{array}$ & $\begin{array}{c}17.5(38 \%) \\
3.5\end{array}$ & $\begin{array}{c}14.6(78 \%) \\
14.2\end{array}$ & $\begin{array}{c}3.4(35 \%) \\
-0.9\end{array}$ & $\begin{array}{c}29.6(49 \%) \\
-3.3\end{array}$ & $\begin{array}{c}19.2(81 \%) \\
23.5\end{array}$ \\
\hline
\end{tabular}

582

583

584 Table 6. Areal first order kinetic constants $\left(k_{A}, m y^{-1}\right)$ for some water quality variables. Values in parenthesis are $\%$ of removal data. In bold, $\mathrm{k}_{\mathrm{A}}$ calculated with the complete dataset

\begin{tabular}{|c|c|c|c|c|c|c|}
\hline & \multirow{2}{*}{$\begin{array}{l}\text { HSSFCW } \\
\text { Sector A } \\
\text { (TMCW) }\end{array}$} & \multicolumn{3}{|c|}{ FWSCWs high vegetated } & \multicolumn{2}{|c|}{ FWSCWs low vegetated } \\
\hline & & $\begin{array}{c}\text { Sector B } \\
\text { (TLICW-1) }\end{array}$ & $\begin{array}{c}\text { Sector B } \\
\text { (TPCW-FG) }\end{array}$ & $\begin{array}{c}\text { Sector B } \\
\text { (TLICW-2) }\end{array}$ & $\begin{array}{l}\text { Sector B } \\
\text { (TMCW) }\end{array}$ & $\begin{array}{c}\text { Sector B } \\
\text { (TPCW-fp) }\end{array}$ \\
\hline COD total & $49.3(100 \%)$ & $3.6(20 \%)$ & $2.9(44 \%)$ & $1.9(20 \%)$ & $2.2(23 \%)$ & $4.4(54 \%)$ \\
\hline $\begin{array}{l}\text { COD } \\
\text { particulate }\end{array}$ & $104.0(100 \%)$ & $\begin{array}{l}-1.8 \\
2.7(50 \%) \\
-3.6\end{array}$ & $\begin{array}{l}1.4 \\
9.5(78 \%) \\
5.8\end{array}$ & $\begin{array}{l}-0.5 \\
4.5(37 \% \text { data }) \\
3.5\end{array}$ & $\begin{array}{l}-4.3 \\
16.4(54 \%) \\
7.7\end{array}$ & $\begin{array}{l}1.5 \\
8.2(54 \%) \\
7.8\end{array}$ \\
\hline COD soluble & $\begin{array}{l}14.4(80 \%) \\
9.7\end{array}$ & $-3.6(100 \%)$ & $\begin{array}{l}2.9(44 \%) \\
0.0\end{array}$ & $-2.6(100 \%)$ & $\begin{array}{l}-6.6(94 \%) \\
-6.1\end{array}$ & $\begin{array}{l}4.4(56 \%) \\
1.1\end{array}$ \\
\hline
\end{tabular}


588 Table 7. Physicochemical characteristics of sediments in CW: mean \pm standard deviation (SD). Percentages 589 refer to wet weight (ww) and dry weight (dw).

\begin{tabular}{lrrrr}
\hline & TPCW & TMCW & TLICW \\
& Mean \pm SD & Mean \pm SD & Mean \pm SD \\
\hline Moisture $(\% \mathrm{ww})$ & $44.7 \pm 9.8$ & $48.4 \pm 8.5$ & $40.7 \pm 7.3$ \\
$\mathrm{LOI}(\% \mathrm{dw})$ & $6.1 \pm 0.9$ & $7.5 \pm 1.1$ & $7.1 \pm 0.8$ \\
$\mathrm{OC}(\% \mathrm{dw})$ & $2.4 \pm 0.6$ & $2.9 \pm 0.6$ & $2.6 \pm 0.5$ \\
$\mathrm{TN}\left(\mathrm{g} \mathrm{kg}^{-1}\right)$ & $2.68 \pm 0.61$ & $3.06 \pm 0.63$ & $2.87 \pm 0.48$ \\
$\mathrm{C} / \mathrm{N} \mathrm{ratio}$ & $9.1 \pm 1.9$ & $9.6 \pm 1.4$ & $9.3 \pm 1.1$ \\
Nitric-N $\left(\mathrm{mg} \mathrm{kg}^{-1}\right)$ & $2.2 \pm 1.8$ & $1.3 \pm 0.6$ & $1.9 \pm 0.7$ \\
Soluble-P $\left(\mathrm{mg} \mathrm{kg}^{-1}\right)$ & $65.9 \pm 31.1$ & $21.6 \pm 8.6$ & $19.7 \pm 11.3$ \\
EC $\left(1: 5,25^{\circ} \mathrm{C}\right)\left(\mathrm{mS} \mathrm{cm}^{-1}\right)$ & $2.23 \pm 1.42$ & $1.94 \pm 1.13$ & $0.91 \pm 0.23$ \\
pH & $7.84 \pm 0.15$ & $7.94 \pm 0.14$ & $8.05 \pm 0.06$ \\
Fraction $<63 \mu \mathrm{mm}$ & $94.1 \pm 2.4$ & $91.0 \pm 4.4$ & $83.6 \pm 5.3$ \\
\hline
\end{tabular}

